\title{
Relevancy of bivalent sulphur excretion to carbon disulphide exposure in different metabolic conditions
}

\author{
L. MAGOS \\ Medical Research Council Laboratories, Toxicology Unit, Woodmansterne Road, \\ Carshalton, Surrey
}

\begin{abstract}
Magos, L. (1972). Brit. J. industr. Med., 29, 90-94. Relevancy of bivalent sulphur excretion to carbon disulphide exposure in different metabolic conditions. A quantitative spectrophotometric method for the estimation of urinary bivalent sulphur by its catalytic effect on the iodine-azide reaction has been developed for rats exposed to carbon disulphide $\left(\mathrm{CS}_{2}\right)$. Urinary $\mathbf{C S}_{2}$ was also determined. Exposure to $\mathbf{C S}_{2}$ increased the excretion of bivalent sulphur in both fed and starved animals, but the increase in starved animals was significantly less than in fed animals. Starvation also decreased the urinary excretion of $\mathbf{C S}_{2}$. Phenobarbitone pretreatment, which induced liver damage in animals subsequently exposed to $\mathrm{CS}_{2}$, had no effect on either bivalent sulphur or $\mathbf{C S}_{2}$ excretion. Three dithiocarbamate fungicides, Thiram, Ziram, and Zineb, given by mouth increased the excretion of bivalent sulphur in the following order: Zineb $<$ Ziram $<$ Thiram.

After $250 \mathrm{mg} / \mathrm{kg}$ sodium diethyldithiocarbamate (DDC) given intraperitoneally the same amount of $\mathrm{CS}_{2}$ was excreted in the urine as after 4 hours' exposure to $2.0 \mathrm{mg} / \mathrm{l} \mathrm{CS_{2 }}$, but the bivalent sulphur excretion was six times higher. Starvation did not decrease the excretion of $\mathrm{CS}_{2}$ or bivalent sulphur after DDC.
\end{abstract}

The metabolic relationship between carbon disulphide $\left(\mathrm{CS}_{2}\right)$, dialkyldithiocarbamate, and tetraalkylthiuramdisulphide is well established. Because there is an increase in the serum concentration of thiol groups as a result of in vitro reaction with $\mathrm{CS}_{2}$ or the exposure of guinea-pigs to $\mathrm{CS}_{2}$ (Souček and Madlo, 1955; 1956), it was proposed by Souček (1957) that the first step in the metabolic pathway of $\mathrm{CS}_{2}$ is its reaction with amino acids and proteins resulting in the formation of dithiocarbamate type compounds. On the other hand, Strömme (1965) has shown that one of the metabolic products of diethyldithiocarbamate and disulfiram (tetraethylthiuram disulphide) is $\mathrm{CS}_{2}$. Within 4 hours after the administration of $25 \mathrm{mg}$ diethyldithiocarbamates to the rat, about $10 \%$ of the sulphur administered was recovered in the exhaled air as
$\mathrm{CS}_{2}$ (Strömme, 1965). After inhalation of $\mathrm{CS}_{2}$ 8 to $30 \%$ of the body burden is exhaled and less than $1 \%$ is excreted in the urine of persons exposed to $\mathrm{CS}_{2}$ (Teisinger and Souček, 1949; Harashima and Masuda, 1962). The low level of urinary excretion indicates that $\mathrm{CS}_{2}$ is either exhaled or nearly completely metabolized. One of the major metabolites of $\mathrm{CS}_{2}$, diethyldithiocarbamate, and disulfiram is sulphate (McKee et al., 1943; Strittmatter, Peters, and McKee, 1950; Strömme, 1965). The second group of major metabolites constitutes compounds which retained sulphur in the bivalent form. Their excretion is the best indicator of the level of $\mathrm{CS}_{2}$ exposure when assayed by using their catalytic effect on the reduction of iodine by azide (Vasak, Venacek, Kimmelova, 1963; Djurić, Surdicki, and Berkes, 1965; Jakubowski and Piotrowski, 1967). 
It seems reasonable to suppose that bivalent sulphur excretion after exposure to $\mathrm{CS}_{\mathbf{2}}$ is related to the detoxification of $\mathrm{CS}_{2}$. It has been reported that, of a group of workers with the same exposure, only those who exhibited a delayed excretion pattern of bivalent sulphur developed symptoms after some months of exposure (Graovac-Leposović, Djurić, Pavlović, and Jovičić, 1967).

As it is difficult to measure exactly human exposure to $\mathrm{CS}_{2}$ or to control those factors which might influence bivalent sulphur excretion, animal experiments offered a better way to investigate factors which might alter the metabolism or the toxicity of $\mathrm{CS}_{2}$. It was found by Bond, Butler, De Matteis, and Barnes (1969) that CS $_{2}$ showed hepatotoxic activity in rats pretreated with phenobarbitone, and Magos and Butler (1971) observed that 24 hours' starvation before exposure made rats treated with phenobarbitone more sensitive to the hepatotoxic effect of $\mathrm{CS}_{2}$. The experiments to be described tried to relate $\mathrm{CS}_{2}$ exposure and bivalent sulphur excretion in rats and also to investigate the effect of starvation and phenobarbitone treatment on the urinary excretion of bivalent sulphur. A sensitive spectrophotometric method has been developed to detect small differences in the catalytic effect of urine on the reduction of iodine by azide. The applicability of the method after the intraperitoneal injection of diethyldithiocarbamate and the oral administration of three different dithiocarbamate fungicides was also tested.

\section{Methods}

Male albino rats of Porton Wistar strain were exposed for 4 hours to $1 \cdot 0,2 \cdot 0$ or $4.0 \mathrm{mg} / \mathrm{l} \mathrm{CS}_{2}$ in a vertical type constant flow exposure chamber (Magos, Emery, Lock, and Firmager, 1970). Phenobarbitone sodium (BDH Chemicals Ltd) was given intraperitoneally in a dose of $80 \mathrm{mg} / \mathrm{kg}$ and $50 \mathrm{mg} / \mathrm{kg} 24$ and 18 hours respectively before exposure. In the starved group food was withdrawn 24 hours before exposure. The average weight of the starved group was $215.44 \pm 8.83 \mathrm{~g}$ (S.D.) 24 hours before exposure and $196.41 \pm 6.08 \mathrm{~g}$ just before exposure. The weights of the fed group were $211 \cdot 35 \pm 88$ and $218.77 \pm$ $8.4 \mathrm{~g}$ respectively. No food was given to the animals either during exposure or in the ensuing 17 hours when they were kept, two to a cage, in metabolism cages. Urine was collected in flasks immersed in cardice-acetone mixture. After the collection period animals were removed and $10 \mathrm{ml}$ distilled water was spread drop by drop on the inner slope of the metabolic cage to wash it down. This increased urine volumes by approximately 9.0 to $9 \cdot 5 \mathrm{ml}$.

Sodium diethyldithiocarbamate (DDC-Hopkin and Williams, Chadwell Heath, Essex) in aqueous solution was given just before the urine collection period intraperitoneally in a volume of $14.3 \mathrm{ml} / \mathrm{kg}$, Tetramethylthiuramdosulphide (Thiram) $48.1 \mathrm{mg} / \mathrm{kg}$, zinc dimethyldithiocarbamate (Ziram) $61 \cdot 2 \mathrm{mg} / \mathrm{kg}$, and zinc ethylenbisdithiocarbamate (Zineb), $55 \cdot 2 \mathrm{mg} / \mathrm{kg}$, all technical grade suspended in water, were given through a stomach canule in a volume of $20 \mathrm{ml} / \mathrm{kg}$ to give an approximately $0.2 \mathrm{mmol} / \mathrm{kg}$ dose. The timing of the food withdrawal followed the same schedule as in the $\mathrm{CS}_{2}$ experiments.

Estimation of $\mathbf{C S}_{\mathbf{2}}$ in urine

Urines were thawed within 1 hour after the end of collection and stored at $4{ }^{\circ} \mathrm{C}$ and examined 3 to 4 hours later. Identical 30-ml impingers were used for both the urine sample and the diethylamine reagent (Viles, 1940). The two impingers were connected by quickfit joints. The inlet of the sample impinger was connected by polyvinyl tubing through a valve with a nitrogen cylinder, and the outlet of the sample impinger was connected with a 50 to $500 \mathrm{ml} / \mathrm{min}$ rotameter. Urine, $20 \mathrm{ml}$, was added to the sample impinger immersed in a $55^{\circ} \mathrm{C}$ water bath, and $7 \mathrm{ml}$ reagent was pipetted into the absorber impinger immersed in melting ice. When less than $20 \mathrm{ml}$ of urine was available, the volume was made up to $20 \mathrm{ml}$ with distilled water. After adjusting the airflow to 100 $\mathrm{ml} / \mathrm{min}$, the polyvinyl tubing fitted into the inlet of the sample impinger was removed for a few seconds and $2 \mathrm{ml}$ glacial acetic acid was injected with a syringe into the inlet tube. After 30 min bubbling the apparatus was dismantled and the optical density of the absorber was read against reagent blank at $430 \mathrm{~nm}$ in a $2-\mathrm{cm}$ cell in a Unicam spectrophotometer. No attempt was made to distinguish between free and bound $\mathrm{CS}_{2}$, as the proportion of $\mathrm{CS}_{2}$ released without acidification depends on the $\mathrm{pH}$ of the urine and the bubbling time.

\section{Estimation of bivalent sulphur in urine}

The method of Strickland, Mack, and Childs (1960) for cystine was modified for the urinary sulphur metabolites of $\mathrm{CS}_{2}$. The iodine-azide reagent was prepared from stock $2 \mathrm{M}$ sodium azide and from stock $\mathrm{KI}_{3}$, containing $0.065 \mathrm{M} \mathrm{I}_{2}$ and $0.130 \mathrm{M} \mathrm{KI}$. Fifty millilitres of the azide solution and $20 \mathrm{ml}$ of the $\mathrm{KI}_{3}$ solution were mixed, the pH was adjusted to $5 \cdot 2$ by adding $5 \mathrm{~N} \mathrm{HCl}$, and diluted to $110 \mathrm{ml}$ with distilled water. Of the chilled reagent $5 \mathrm{ml}$ was pipetted into 50-ml glass-stoppered flasks immersed in melting ice. The overnight urine of two animals was made up to $100 \mathrm{ml}$ (or more if high activity made it necessary). From the diluted urine $1 \mathrm{ml}$ was added to the reagent, and by rotation complete mixing was achieved. Flasks were loosely closed with glass stoppers used upside down. Blanks were incubated with $1 \mathrm{ml}$ of distilled water. After $30 \mathrm{~min}$ incubation $50 \mathrm{ml}$ distilled water was added to both blanks and samples, and immediately after that $5 \mathrm{ml}$ of the diluted sample was pipetted into $5 \mathrm{ml}$ carbon tetrachloride. After shaking for 30 seconds, time was allowed for the phases to separate. The carbon tetrachloride phase was transferred to a $1 \mathrm{~cm}$ cell and the absorbancy was read against water-saturated carbon tetrachloride at $525 \mathrm{~nm}$. The solution obeys Beer's law and from the difference between blanks and samples the amount of iodine reduced to iodide by the total urine per $\mathrm{kg}$ of body weight was calculated. Using diethyldithiocarbamate instead of urine, $1 \mu \mathrm{mol}$ DDC reduced $120 \mu \mathrm{mol} \mathrm{I}_{2}$.

All the urinary excretion values of $\mathrm{CS}_{2}$-exposed rats were related to the body weight taken 24 hours before exposure. In the case of DDC or fungicides the dose and the excretions were calculated on the basis of weight at the time of injection. 


\section{Results}

Figure 1 shows that the excretion of bivalent sulphur increased significantly in fed and starved rats when exposure was increased from $1.0 \mathrm{mg} / 1$ up to $4.0 \mathrm{mg} / \mathrm{l}$. However, in the fed rats the increase in excretion after exposure to $1.0 \mathrm{mg} / 1$ compared to unexposed rats was much greater than in the starved rats, although thereafter the same increment in exposure caused the same increment in bivalent sulphur excretion in both fed and starved animals. The difference in the excretion of bivalent sulphur by fed and starved rats was significant at every level of exposure.

Table 1 shows that phenobarbitone pretreatment had no effect on the excretion of bivalent sulphur in either fed or starved animals. Urinary $\mathrm{CS}_{2}$ excretion was also influenced by starvation, but not by phenobarbitone (Table 2). Starvation resulted in an approximately $50 \%$ decrease in the excretion of $\mathrm{CS}_{2}$. Actually in starved animals exposed to $2.0 \mathrm{mg} / 1$ $\mathrm{CS}_{2}$, the $\mathrm{CS}_{2}$ excretion was the same as in fed animals exposed to $1.0 \mathrm{mg} / \mathrm{l} \mathrm{CS}_{2}$.

Figure 2 shows that animals treated with 250 $\mathrm{mg} / \mathrm{kg}$ DDC excreted as much $\mathrm{CS}_{2}$ as rats exposed to $2.0 \mathrm{mg} / 1 \mathrm{CS}_{2}$, but the urine of the former group of animals was six times more efficient in catalysing the reduction of iodine by azide than the urine of the latter. Figure 2 also shows that neither the ex-

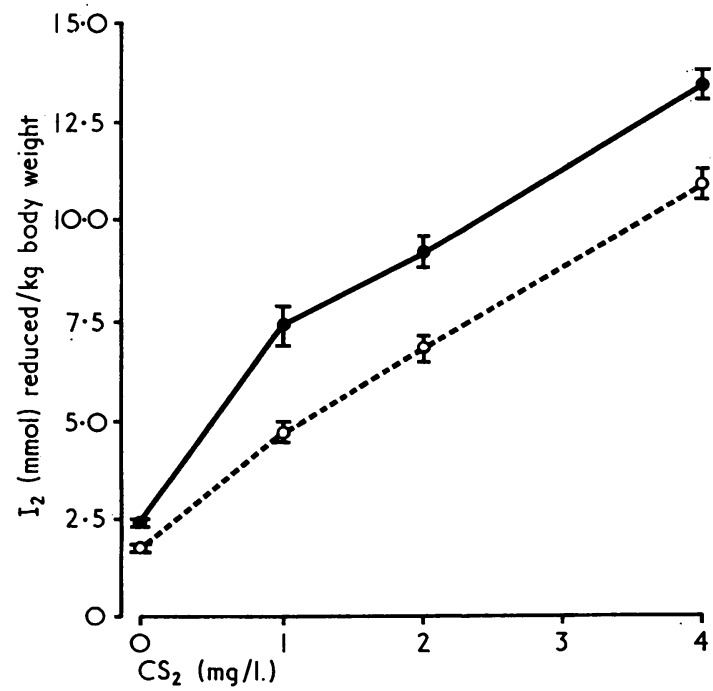

FIG. 1. Effect of 4 hours' exposure to $\mathrm{CS}_{2}$ on urinary excretion of bivalent sulphur in fed (straight line) and starved (broken line) male rats. Starving started 24 hours before exposure; urine was collected in the first 17 hours after exposure. Bivalent sulphur was estimated from the catalytic effect of urine on the reduction of iodine by azide. The vertical lines mark the standard errors of means.
TABLE 1

Effects of Starvation and Phenobarbitone PreTREATMENT ON BIVALENT SUlPHUR EXCRETION IN RATS EXPOSED TO $\mathrm{CS}_{2}$

\begin{tabular}{c|c|cc}
\hline $\begin{array}{c}\text { Phenobarbitone } \\
\text { treatment }\end{array}$ & $\begin{array}{c}4 \mathrm{~h} . \\
\text { exposure } \\
\text { to } 2 \mathrm{mg} / \mathrm{l}\end{array}$ & $\begin{array}{c}\text { mmol } \mathrm{I}_{2} \text { reduced by total } \\
\text { urine/ } \mathrm{kg} \text { of body weight }\end{array}$ \\
\cline { 3 - 4 } & $\mathrm{CS}_{2}$ & Fed & Starved \\
\hline- & - & $2 \cdot 44(0 \cdot 11)$ & $1 \cdot 81(0 \cdot 05)^{1}$ \\
& & $\mathrm{~N}=8$ & $\mathrm{~N}=8$ \\
+ & - & $2 \cdot 61(0 \cdot 14)$ & $1 \cdot 93(0 \cdot 10)^{1}$ \\
- & & $\mathrm{N}=8$ & $\mathrm{~N}=8$ \\
& + & $9 \cdot 38(0 \cdot 33)$ & $6 \cdot 91(0 \cdot 30)^{1}$ \\
+ & & $\mathrm{N}=16$ & $\mathrm{~N}=16$ \\
& + & $9 \cdot 46(0 \cdot 36)$ & $7 \cdot 50(0 \cdot 27)^{1}$ \\
& & $\mathrm{~N}=18$ & $\mathrm{~N}=18$ \\
\hline
\end{tabular}

${ }^{1}$ Significant difference between fed and starved is $P<0.005$. There is no significant difference between phenobarbitonetreated and untreated rats.

Starvation started 24 hours before exposure; phenobarbitone sodium was given intraperitoneally 24 and 18 hours before exposure in doses of 80 and $50 \mathrm{mg} / \mathrm{kg}$ respectively. Urine was collected in the first $\mathbf{1 7}$ hours after exposure. Numbers in parathenses are the standard errors of means.

cretion of $\mathrm{CS}_{2}$ nor bivalent sulphur was decreased by starvation after the administration of diethyldithiocarbamate. Actually in starved rats at the two higher doses, the excretion values were higher than

TABLE 2

Effect of Starvation and Phenobarbitone PreTREATMENT ON URINARY EXCRETION OF $\mathrm{CS}_{2}$

\begin{tabular}{|c|c|c|c|}
\hline \multirow{2}{*}{$\begin{array}{c}\text { Level of } C S_{2} \\
\text { exposure }(m g / l) \\
(4 h)\end{array}$} & \multirow[t]{2}{*}{$\begin{array}{l}\text { Phenobarbitone } \\
\text { pretreatment }\end{array}$} & \multicolumn{2}{|c|}{$\begin{array}{c}\text { Urinary excretion of } \mathrm{CS}_{2} \\
(\mu \mathrm{mol} / \mathrm{kg})\end{array}$} \\
\hline & & Fed & Starved \\
\hline 1.0 & - & $\begin{array}{c}0.50(0.05) \\
N=8\end{array}$ & - \\
\hline $2 \cdot 0$ & - & $0.89(0.07)$ & $0.45(0.07)^{1}$ \\
\hline $2 \cdot 0$ & + & $\begin{array}{c}0.87(0.09) \\
N=8\end{array}$ & $\begin{array}{c}0.37(0.07)^{2} \\
N=8\end{array}$ \\
\hline $4 \cdot 0$ & - & $\begin{array}{c}1 \cdot 36(0 \cdot 16) \\
N=8\end{array}$ & - \\
\hline
\end{tabular}

1Significant difference between fed and starved animals is $P<0.005$. There is no statistically significant difference between phenobarbitone-treated and untreated rats.

Starvation started 24 hours before exposure; phenobarbitone sodium was given intraperitoneally 24 and 18 hours before exposure in doses of 80 and $50 \mathrm{mg} / \mathrm{kg}$ respectively. Urine was collected in the first 17 hours after exposure. Numbers in parentheses are the standard errors. 


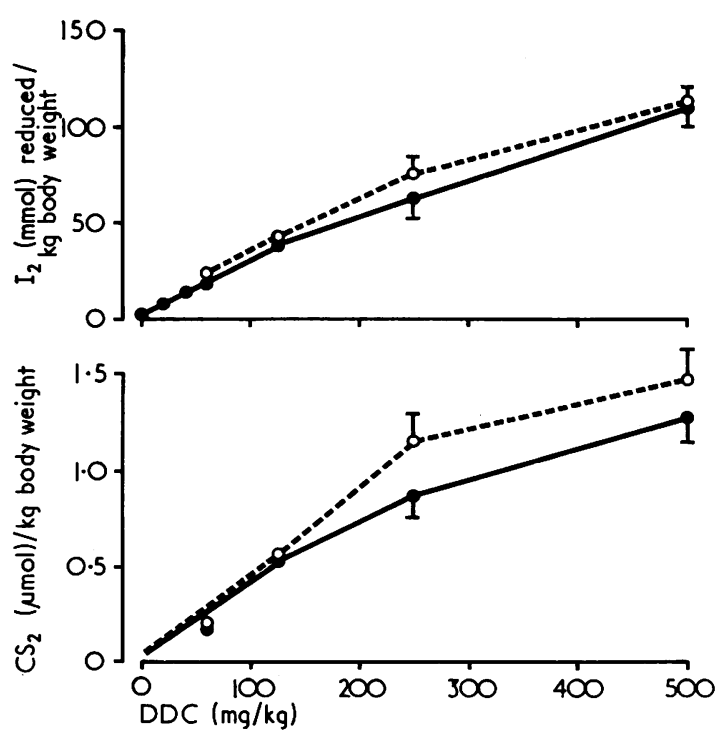

FIG. 2. Effect of sodium diethyldithiocarbamate on urinary excretion of $\mathrm{CS}_{2}$ and bivalent sulphur in fed (straight line) and starved (broken line) rats. DDC was given intraperitoneally and urine was collected in the next 17 hours. One sample was obtained from two animals. Every point represents the mean value of three samples. Vertical bars mark the standard errors of means.

in fed animals, but the differences were not significant.

All the three dithiocarbamate fungicides increased bivalent sulphur excretion. The increase in the reduction of iodine by urine after the administration of $\mathbf{0 . 2} \mathrm{mmol} / \mathrm{kg}$ Thiram, Ziram, and Zineb was $8.95,3.66$, and $1.62 \mathrm{mmol} \mathrm{I}_{2} / \mathrm{kg}$ of body weight, respectively.

\section{Discussion}

The increase in bivalent sulphur excretion is not specific for $\mathrm{CS}_{2}$ exposure. Novak, Djurić and Fridman (1969) reported that the urine of persons treated with disulfiram was more effective in catalysing the iodine-azide reaction than the urine of control persons. The results presented here have shown that rats treated with dithiocarbamate fungicides like Thiram, Ziram, and Zineb or injected with sodium diethyldithiocarbamate also excreted significantly more bivalent sulphur than control rats. Of the three dithiocarbamate fungicides, Thiram, a compound closely related to disulfiram, was the most effective.

In spite of the close metabolic and pharmacological relationship between $\mathrm{CS}_{2}$ and sodium diethyldithiocarbamate (Magos and Jarvis, 1970a, 1970b) the proportion of $\mathrm{CS}_{2}$ to bivalent sulphur in the urine of rats exposed to $\mathrm{CS}_{2}$ or treated with $\mathrm{DDC}$ is not similar. Thus rats dosed with $250 \mathrm{mg} / \mathrm{kg}$ DDC excreted the same amount of $\mathrm{CS}_{2}$ as rats exposed for 4 hours to $2.0 \mathrm{mg} / \mathrm{l}$ when the estimated uptake is approximately $0.9 \mathrm{mmol} / \mathrm{kg} \mathrm{CS}$ but they excreted six times as much bivalent sulphur. The bivalent sulphur metabolite of $\mathrm{CS}_{2}$ cannot be dithiocarbamate-type compounds as unconjugated dithiocarbamates should give the same results with the bivalent sulphur estimation using the conversion factor of $1 \mu \mathrm{mol} \mathrm{DDC}=120 \mu \mathrm{mol} I_{2}$ as with the carbon disulphide evolution method. Furthermore, judged from the different effects of starvation on bivalent sulphur excretion in DDC treated and $\mathrm{CS}_{2}$ exposed rats, it is unlikely that the metabolite is a conjugated dithiocarbamate which is the main metabolic product after DDC (Strömme, 1965).

Contrary to expectations, phenobarbitone pretreatment, which renders the liver cells more sensitive to damage by $\mathrm{CS}_{2}$, had no effect on either $\mathrm{CS}_{2}$ or bivalent sulphur excretion, suggesting that the effect of phenobarbitone on carbon disulphide hepatotoxicity may not be mediated through altered $\mathrm{CS}_{2}$ metabolism. However, it must be pointed out that the amounts of $\mathrm{CS}_{2}$ and bivalent sulphur excreted after exposure to $\mathrm{CS}_{2}$ probably reflect only a small part of the net $\mathrm{CS}_{2}$ uptake (uptake by inhalation minus release by exhalation).

It might be expected that if less $\mathrm{CS}_{2}$ is converted to bivalent sulphur, the more $\mathrm{CS}_{2}$ would be excreted. However, 24 hours' starvation before exposure significantly decreased the amount of both bivalent sulphur and $\mathrm{CS}_{2}$ excreted by the animals within 17 hours after exposure. One possible explanation of this finding is that in starved rats the cell constituents were able to bind more $\mathrm{CS}_{2}$ without a corresponding increase in the formation of bivalent sulphur. Another explanation could be that starvation increased the metabolism of $\mathrm{CS}_{2}$ which leads to non-bivalent sulphur end-products.

It would be interesting to know whether bivalent sulphur excreted as a result of exposure to $\mathrm{CS}_{2}$ consists of one or more compounds produced by one or several reactions. As the straight line drawn through the bivalent sulphur excretion values of starved animals intercepts the ordinate at their normal value, it seems reasonable to suppose that one type of compound or one type of reaction is responsible for their bivalent sulphur excretion. However, in the case of fed animals this reaction appears to be supplemented by another type of compound of limited availability. This additional metabolic pathway-if it is present in men-might explain individual differences in sensitivity to the toxic effects of $\mathrm{CS}_{2}$.

The author wishes to thank Mrs. A. R. Green for valuable technical assistance. 


\section{References}

Bond, E. J., Butler, W. H., De Matteis, F., and Barnes, J. M. (1969). Effects of carbon disulphide on the liver of rats. Brit. J. industr. Med., 26, 335-337.

Djurić, D., Surducki, N., and Berkes, I. (1965). Iodine-azide test on urine of persons exposed to carbon disulphide. Brit. J. industr. Med., 22, 321-323.

Graovac-Leposavić, Lj., Djurić, D., Pavlović, A., and Jovičić, M. (1967). The use of the iodine-azide test for the early diagnosis of carbon disulphide poisoning. Toxicology of Carbon Disulphide. Proceedings of a Symposium, Prague, 1966, edited by H. Brieger and J. Teisinger, pp. 62-69. Excerpta Medica Foundation, Amsterdam.

Harashima, S., and Masuda, Y (1962) Quantitative determination of absorption and elimination of carbon disulfide through different channels in human body. Arch. Gewerbepath. Gewerbehyg., 19, 263-269.

Jakubowski, M., and Piotrowski, J. (1967). Practical evaluation of the iodine-azide test for the estimation of exposure to carbon disulphide. In Toxicology of Carbon Disulphide: Proceedings of a Symposium, Prague, 1966, edited by $\mathrm{H}$. Brieger and J. Teisinger, pp. 70-75. Excerpta Medica Foundation, Amsterdam.

Magos, L., and Butler, W. H. (1971). Effect of phenobarbitone and starvation on hepatotoxicity in rats exposed to carbon disulphide vapour. Brit. J. industr. Med., 29, 000-000.

_-, Emery, R. C., Lock, R. D., and Firmager, B. G. (1970). A vertical-type constant flow inhalation chamber for rats. Lab. Pract., 19, 725-727.

- and Jarvis, J. A. E. (1970a). The effects of carbon disulphide exposure on brain catecholamines in rats. Brit. J. Pharmacol., 39, 26-33.

- and - (1970b). Effects of diethyldithiocarbamate and carbon disulphide on brain tyrosine. J. Pharm. Pharmacol., 22, 936-938.

McKee, R. W., Kiper, C., Fountain, J. H., Riskin, A. M., and Drinker, P. (1943). A solvent vapor, carbon disulfide. Absorption, elimination, metabolism and mode of action. J. Amer. med. Ass., 122, 217-222.

Novak, L., Djurić, D., and Fridman, V. (1969). Specificity of the iodine-azide test for carbon disulfide exposure. Arch. environm. Hlth, 19, 473-477.

Souček, B. (1957). Unwandlung von Schwefelkohlenstoff im Organismus. J. Hyg. Epidem. (Praha), 1, 10-22.

- and Mádlo, Z. (1955). Détermination des groupements sulfhydrilés dans le sérum sanguin après l'exposition dans le sulfure de carbone. Bull. Soc. Chim. biol., 37, 1373-1378.

and - (1956). Dithiocarbamincarbonsäuren als Abbauprodukte des Schwefelkohlenstoffs. Arch. Gewerbepath. Gewerbehyg., 14, 511-521.

Strickland, R. D., Mack, P. A., and Childs, W. A. (1960). Determination of cystine by its catalytic effect on the iodine-azide reaction. Analyt. Chem., 32, 430-436.

Strittmatter, C. F., Peters, T., Jr., and McKee, R. W. (1950). Metabolism of labeled carbon disulfide in guinea pigs and mice. Arch. industr. Hyg., 1, 54-64.

Strömme, J. H. (1965). Metabolism of disulfiram and diethyldithiocarbamate in rats with demonstration of an in vivo ethanol-induced inhibition of the glucuronic acid conjugation of the thiol. Biochem. Pharmacol., 14, 393-410.

Teisinger, J., and Souček, B. (1949). Absorption and elimination of carbon disulfide in man. J. industr. Hyg., 31, 67-73.

Vasak, V., Vanacek, M., and Kimmelova, G. (1963). Assessment of exposure of workers to carbon disulphide vapours. II. Application of the iodine-azide reaction for the detection and estimation of carbon disulphide metabolites in urine. (Czech. with English summary). Pracov. Lék., 15, 145-149.

Viles, F. J. (1940). Field determination of carbon disulphide in air. J. industr. Hyg., 22, 188-196.

Received for publication April 3, 1971 